Case Report

\title{
Hypothermia in Multiple Sclerosis: Beyond the Hypothalamus? A Case Report and Review of the Literature
}

\author{
Francesco Berti $\mathbb{D}$, ${ }^{1}$ Zeeshan Arif $\mathbb{D}$, ${ }^{1}$ Cris Constantinescu $\mathbb{D}$, ${ }^{1,2}$ and Bruno Gran $\mathbb{D}^{2}$ \\ ${ }^{1}$ Division of Clinical Neuroscience, University of Nottingham School of Medicine, Nottingham, UK \\ ${ }^{2}$ Department of Neurology, Nottingham University Hospitals NHS Trust, Nottingham, UK \\ Correspondence should be addressed to Bruno Gran; bruno.gran@nuh.nhs.uk
}

Received 18 August 2017; Revised 6 January 2018; Accepted 6 February 2018; Published 21 March 2018

Academic Editor: Isabella Laura Simone

Copyright (c) 2018 Francesco Berti et al. This is an open access article distributed under the Creative Commons Attribution License, which permits unrestricted use, distribution, and reproduction in any medium, provided the original work is properly cited.

\begin{abstract}
Hypothermia is a rare and poorly understood complication of Multiple Sclerosis (MS). We report on a 66-year-old patient currently with Secondary Progressive MS (SP-MS) who developed unexplained hypothermia associated with multiple hospitalisations and we review the literature on this topic. In our case, magnetic resonance imaging (MRI) of the brain failed to highlight hypothalamic disease, but spinal MRI identified a number of spinal cord lesions. Given the incidence and clinical significance of spinal involvement in MS and the hypothermic disturbances observed in high Spinal Cord Injury (SCI), we hypothesise that upper spinal cord pathology, along with hypothalamic and brainstem dysfunctions, can contribute to hypothermia.
\end{abstract}

\section{Introduction}

Multiple Sclerosis (MS) is the most common demyelinating disease and the major cause of neurological disability among young adults, affecting at least 2.5 million persons worldwide [1].

The cause of MS is unknown, but strong evidence suggests it is an autoimmune disorder of the central nervous system (CNS) where a chronic inflammatory response develops against myelin autoantigens leading to demyelination, scarring, and neuronal loss [2]. The multifocal nature of the disease implies that it can occur anywhere within the white and grey matter of the brain and spinal cord; thus its symptomatology can markedly differ based on the localisation of the lesions [1].

Radiological detection of multiple plaques and areas of atrophy is suggestive of MS, but the clinical correlation is often weak, with the absence of such findings failing to explain some dysfunctions [3]. Clinical hypothermia, defined as a core body temperature below $35.0^{\circ} \mathrm{C}$ [4], is an example of a rare and puzzling manifestation associated with MS. Hypothalamic pathology is considered its main cause but has been radiologically identified in very few of such MS patients.

In this article, we report on an hypothermic MS patient and review the literature on this subject, focusing on exploring whether extrahypothalamic dysfunctions along the thermoregulatory network may contribute to the development of this complication.

\section{Case Presentation}

A 66-year-old lady with a 21-year history of clinically definite MS, currently in the Secondary Progressive MS (SP-MS) phase, was admitted to hospital 14 times within a twoyear period. On 10 occasions this was due to unexplained symptoms such as fatigue, confusion, worsening mobility, and dysarthria associated with hypothermia and suspected urinary tract infections (UTIs) (see Table 1).

Before these admissions, the patient was clinically stable with an Expanded Disability Status Scale (EDSS) score of 6.5 and had been hospitalised only once in the previous eight years, for cellulitis in the legs. At the time, she was suffering from limb weakness (mostly in the legs), spasticity, severe fatigue, reduced hand dexterity, and blepharospasm, but no other comorbidity. She could walk for 20 metres with a supporting frame but was otherwise wheelchair dependent. Since 2005, she had been receiving Botulinum Toxin injections for lower limb spasticity and blepharospasm and was on a trial of low-dose Naltrexone. The patient was also suffering from 
TABLE 1: Summary of patient admissions to hospital between March 2013 and March 2015.

\begin{tabular}{|c|c|c|c|c|c|c|c|}
\hline $\begin{array}{l}\text { Admission } \\
\text { date }\end{array}$ & $\begin{array}{c}\text { Main } \\
\text { complaint(s) }\end{array}$ & $\begin{array}{c}\text { Temperature } \\
\text { at admission } \\
\left({ }^{\circ} \mathrm{C}\right)\end{array}$ & New finding(s) & $\begin{array}{l}\text { Confirmed } \\
\text { diagnosis }\end{array}$ & Treatment(s) & $\begin{array}{l}\text { Disease } \\
\text { course }\end{array}$ & Neuroimaging \\
\hline $\begin{array}{l}\text { 24 March } \\
2013\end{array}$ & $\begin{array}{l}\text { Confusion, } \\
\text { dysarthria, } \\
\text { reduced } \\
\text { mobility, and } \\
\text { recent falls }\end{array}$ & 34.6 & $\begin{array}{c}\text { GCS }(10 / 15) \\
\text { Leukopaenia } \\
\text { Hyponatraemia } \\
(\text { Na+ } 131 \text { mmol/l), } \\
\text { mildly deranged } \\
\text { LFTs } \\
\text { Normal LP, CXR, } \\
\text { and abdominal } \\
\text { USS }\end{array}$ & $\begin{array}{l}\text { No ?SUO } \\
\text { ?SIADH }\end{array}$ & $\begin{array}{c}\text { IV } \\
\text { antibiotics, } \\
\text { naltrexone } \\
\text { discontinued } \\
\text { because of } \\
\text { LFTs }\end{array}$ & $\begin{array}{l}\text { Discharged } \\
\text { in } 3 \text { weeks } \\
\text { (homeother- } \\
\text { mic) with } \\
\text { care package } \\
\text { and } \\
\text { rehabilitation }\end{array}$ & $\begin{array}{c}\text { Head CT and brain } \\
\text { MRI. } \\
\text { No acute findings. } \\
\text { Bilateral, } \\
\text { white-matter } \\
\text { changes and } \\
\text { generalised } \\
\text { atrophy. } \\
\text { No hypothalamic } \\
\text { involvement }\end{array}$ \\
\hline 18 July 2013 & $\begin{array}{c}\text { Urinary } \\
\text { incontinence, } \\
\text { oedema, and } \\
\text { cellulitis }\end{array}$ & 35.8 & No & No ?UTI & Antibiotics & Discharged & No \\
\hline $\begin{array}{l}18 \text { October } \\
2013\end{array}$ & $\begin{array}{c}\text { Confusion } \\
\text { lethargy, } \\
\text { dysarthria, } \\
\text { worsening } \\
\text { movements, and } \\
\text { decreased taste }\end{array}$ & 33.5 & $\begin{array}{c}\text { Nystagmus } \\
\text { Diplopia } \\
\text { Decreased limb } \\
\text { power } \\
\text { Hyponatraemia } \\
\text { (127 mmol/l), } \\
\text { normokalaemia } \\
\text { (4.4 mmol/l) } \\
\text { Hyposmolarity } \\
\text { (serum osmolality: } \\
269 \mathrm{mOsm} / \mathrm{kg} ; \\
\text { Urine Osmolality: } \\
368 \mathrm{mOsm} / \mathrm{kg}) \\
\end{array}$ & $\begin{array}{c}\text { No } \\
\text { ?SIADH }\end{array}$ & Supportive & $\begin{array}{l}\text { Discharged } \\
\text { in } 5 \text { days } \\
\text { while still } \\
\text { hypothermic } \\
\left(T: 34.3^{\circ} \mathrm{C}\right)\end{array}$ & No \\
\hline $\begin{array}{l}7 \text { November } \\
2013\end{array}$ & $\begin{array}{l}\text { Dizziness on } \\
\text { standing }\end{array}$ & 33.0 & No & No & Supportive & Discharged & No \\
\hline $\begin{array}{l}31 \text { December } \\
2013\end{array}$ & $\begin{array}{l}\text { Lethargy, } \\
\text { unwell, } \\
\text { dysarthria, } \\
\text { and limb } \\
\text { weakness }\end{array}$ & 33.0 & $\begin{array}{c}\text { Bradycardia, } \\
\text { normal } \\
\text { liver autoimmune } \\
\text { screen, Vitamin D, } \\
\text { TFTs, prolactin, } \\
\text { PTH, calcium, and } \\
\text { random cortisol }\end{array}$ & No ?UTI & Antibiotics & $\begin{array}{c}\text { Discharged } \\
\text { in } 2 \text { weeks }(T: \\
\left.34.0^{\circ} \mathrm{C}\right)\end{array}$ & $\begin{array}{c}\text { Brain MRI: no } \\
\text { acute findings. } \\
\text { Heavy } \\
\text { demyelinating } \\
\text { disease burden and } \\
\text { a likely incidental } \\
\text { small frontal } \\
\text { meningioma. } \\
\text { No hypothalamic } \\
\text { involvement }\end{array}$ \\
\hline $\begin{array}{l}16 \text { March } \\
2014\end{array}$ & $\begin{array}{c}\text { Feeling cold, } \\
\text { unwell, and } \\
\text { dysarthria }\end{array}$ & 32.8 & $\begin{array}{l}\text { RUQ tenderness } \\
\text { Murphy's +ve. } \\
\text { Abdominal USS: } \\
\text { cholelithiasis and } \\
\text { contracted gall } \\
\text { bladder }\end{array}$ & No & $\begin{array}{l}\text { Antibiotics } \\
\text { then } \\
\text { supportive }\end{array}$ & $\begin{array}{l}\text { Discharged } \\
\text { in } 2 \text { weeks }\end{array}$ & No \\
\hline 22 May 2014 & Weakness & 33.1 & $\begin{array}{c}\text { Positive MSU, CRP } \\
41 \\
\end{array}$ & UTI & Antibiotics & $\begin{array}{l}\text { Discharged } \\
\text { the next day }\end{array}$ & No \\
\hline 27 May 2014 & $\begin{array}{l}\text { Feeling cold and } \\
\text { weakness }\end{array}$ & 33.7 & No & No & Supportive & $\begin{array}{l}\text { Discharged } \\
\text { in } 3 \text { days }\end{array}$ & No \\
\hline $\begin{array}{l}15 \text { September } \\
2014\end{array}$ & Right flank pain & 32.7 & $\begin{array}{l}\text { Urinalysis (positive } \\
\text { for leukocites and } \\
\text { blood }+++ \text { ) }\end{array}$ & UTI & Antibiotics & $\begin{array}{l}\text { Discharged } \\
\text { in a week }\end{array}$ & No \\
\hline
\end{tabular}


TABLE 1: Continued.

\begin{tabular}{|c|c|c|c|c|c|c|c|}
\hline $\begin{array}{l}\text { Admission } \\
\text { date }\end{array}$ & $\begin{array}{c}\text { Main } \\
\text { complaint(s) }\end{array}$ & $\begin{array}{c}\text { Temperature } \\
\text { at admission } \\
\left({ }^{\circ} \mathrm{C}\right)\end{array}$ & New finding(s) & $\begin{array}{c}\text { Confirmed } \\
\text { diagnosis }\end{array}$ & Treatment(s) & $\begin{array}{l}\text { Disease } \\
\text { course }\end{array}$ & Neuroimaging \\
\hline $\begin{array}{l}2 \text { October } \\
2014\end{array}$ & $\begin{array}{l}\text { Right flank pain, } \\
\text { urinary } \\
\text { incontinence, } \\
\text { confusion, and } \\
\text { persistently low } \\
\text { temperatures }\end{array}$ & 34.0 & No & $\begin{array}{c}\text { AKI and } \\
\text { ?UTI }\end{array}$ & Antibiotics & $\begin{array}{l}\text { Discharged } \\
\text { in } 6 \text { days }\end{array}$ & No \\
\hline
\end{tabular}

\begin{tabular}{|c|c|c|c|}
\hline $\begin{array}{l}12 \text { October } \\
2014\end{array}$ & $\begin{array}{c}\text { Dysarthria, } \\
\text { fatigue, } \\
\text { confusion, } \\
\text { weakness, and } \\
\text { decreased power }\end{array}$ & NK & $\begin{array}{c}\text { Hyponatraemia, } \\
\text { hyperkalaemia } \\
(\mathrm{Na}+125 \mathrm{mmol} / \mathrm{l}, \\
\mathrm{K}+5.8 \mathrm{mmol} / \mathrm{l}), \\
\text { eGFR 59, urea } \\
8.4 \mathrm{mmol} / \mathrm{l} \\
\text { MSU (positive for } \\
\text { leukocytes) } \\
\text { Mixed growth, } \\
\text { possible } \\
\text { contamination }\end{array}$ \\
\hline
\end{tabular}

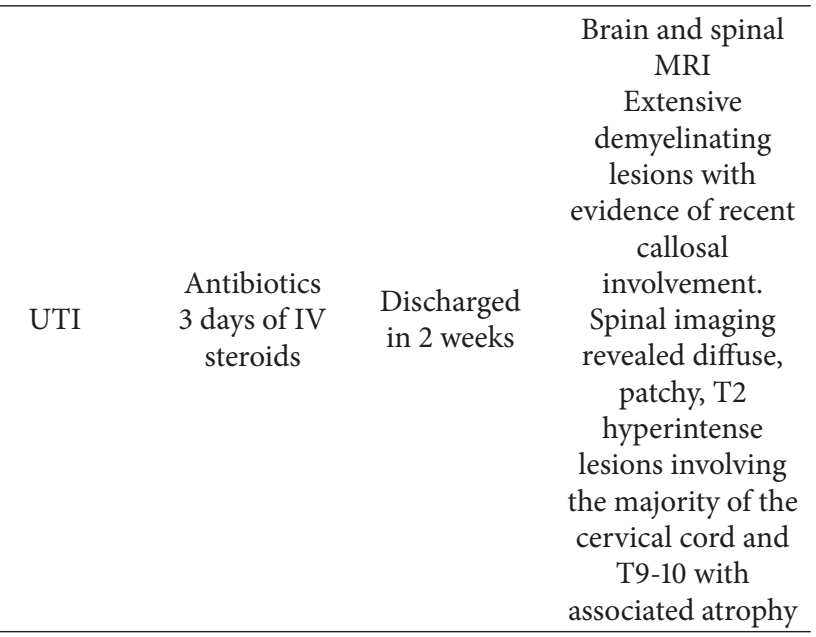

\begin{tabular}{|c|c|c|c|c|c|c|c|}
\hline $\begin{array}{l}24 \text { October } \\
2014\end{array}$ & $\begin{array}{l}\text { Neck pain, } \\
\text { fatigue, and } \\
\text { weakness }\end{array}$ & 37.4 & No & No ?UTI & Antibiotics & NK & No \\
\hline $\begin{array}{l}\text { 23 March } \\
2015\end{array}$ & Lethargy & 31.0 & No & No? UTI & Supportive & $\begin{array}{l}\text { Discharged } \\
\text { on same day }\end{array}$ & No \\
\hline $\begin{array}{l}25 \text { March } \\
2015\end{array}$ & $\begin{array}{l}\text { Lethargy and } \\
\text { high- } \\
\text { temperature }\end{array}$ & 37.0 & $\begin{array}{c}\text { Dysmetric } \\
\text { saccades. } \\
\text { Cerebellar signs. } \\
\text { Worsening power } \\
\text { with bilateral } \\
\text { upgoing plantar } \\
\text { reflexes. } \\
\text { Bilateral lower leg } \\
\text { oedema. }\end{array}$ & No & Supportive & $\begin{array}{c}\text { Discharged } 2 \\
\text { days later }\end{array}$ & No \\
\hline
\end{tabular}

Not known (NK); Glasgow Coma Scale (GCS); acute kidney injury (AKI); mid-stream urine (MSU); C-reactive protein (CRP); right upper quadrant (RUQ); sepsis of unknown origin (SUO); liver function tests (LFTs); lumbar puncture (LP); chest X-ray (CXR); ultrasonography (USS); thyroid function tests (TFTs); parathyroid hormone (PTH); estimated glomerular filtration rate (eGFR); Syndrome of Inappropriate Anti-Diuretic Hormone (SIADH).

chronic urinary retention and constipation, for which she was taking an osmotic laxative. She had established normocytic anaemia and mildly elevated liver enzymes.

After repeated admissions with hypothermia, she developed chronically low body temperature $\left(T: 34.0-36.0^{\circ} \mathrm{C}\right)$ and by March 2015, she had become bed-bound for most of the day (EDSS $=8.5$ ) and was practising intermittent selfcatheterisation.

She was first found hypothermic in March 2013 after an admission for confusion (GCS 10/15), dysarthria, and reduced mobility (see Table 1 ). The patient had progressively deteriorated in the preceding weeks and had suffered two falls. On admission, her temperature was $34.6^{\circ} \mathrm{C}$, but respiratory rate $(\mathrm{RR})$, heart rate (HR), blood pressure $(\mathrm{BP})$, and $\mathrm{O}_{2}$ saturations were unremarkable. Of note, no shivering or cold sensations were mentioned. Blood tests showed leukopenia, mild hyponatraemia $(131 \mathrm{mmol} / \mathrm{l})$ with normal $\mathrm{K}+$ levels $(4.6 \mathrm{mmol} / \mathrm{l})$, and acutely elevated Liver Function Tests (LFTs) with particularly high aminotransferases. Clotting tests and spinal fluid analysis (lumbar puncture; LP) results were within normal ranges. Chest X-ray (CXR) and abdominal ultrasonography (USS) were unremarkable. Computerised tomography (CT) scan of the head showed no evidence of acute findings.

Magnetic resonance imaging (MRI) of the brain using a 3 Tesla (T) scanner was performed with and without contrast. No old brain scans were available for comparison; however bilateral, white-matter changes and generalised atrophy consistent with MS were reported. No hypothalamic involvement was detected and spinal MRI was not performed. 


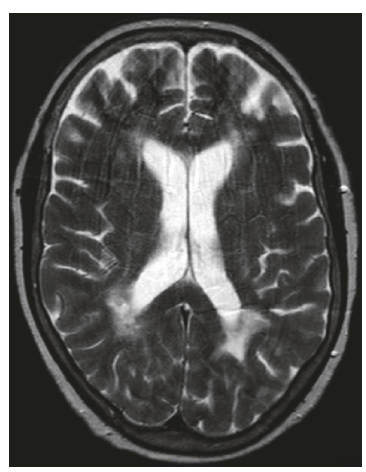

(a)

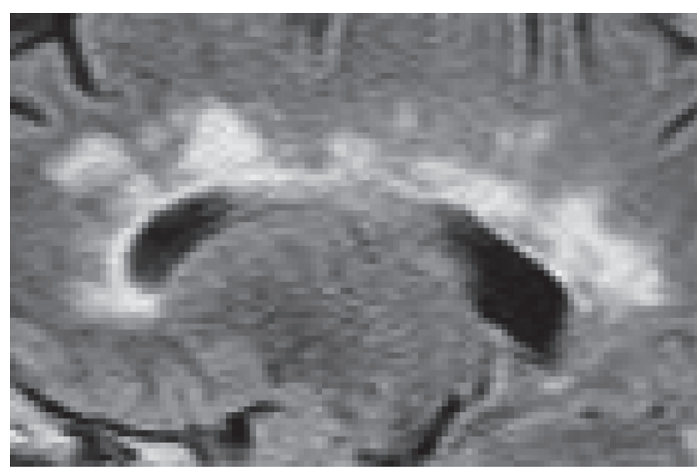

(b)

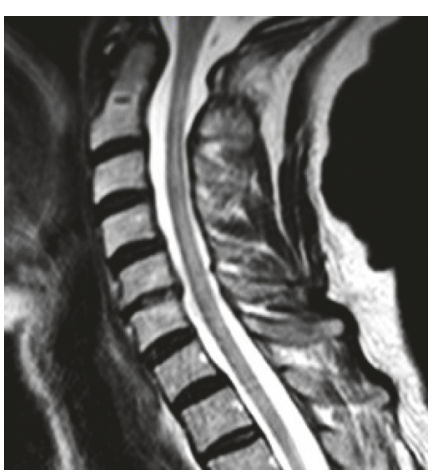

(c)

FIGURE 1: Brain and spinal MRI of the patient following admission on 12 October 2014. (a) Brain T2W axial MRI (1.5 T) demonstrating the characteristic periventricular lesions of MS. (b) Magnification of brain FLAIR sagittal MRI showing involvement of the corpus callosum. (c) Sagittal T2W spinal MRI of the cervical cord with diffuse, patchy lesions. T2W: T-2 weighted; FLAIR: Fluid-Attenuated Inversion Recovery; T: Tesla.

The cause of her symptoms was not identified and the patient was treated prophylactically for Sepsis of Unknown Origin (SUO) with IV tazocin for five days. She was reviewed by general medicine and neurology and a diagnosis of Syndrome of Inappropriate Anti-Diuretic Hormone (SIADH) secretion with impaired temperature regulation secondary to MS was considered. Naltrexone was discontinued in consideration of her elevated liver enzymes. The patient gradually improved over the next three weeks and was transferred to rehabilitation services before being discharged in June with a care package.

In July 2013, she was rehospitalised because of symptoms of urinary incontinence, leg oedema, and cellulitis and was treated prophylactically for a Urinary Tract Infection (UTI) (see Table 1).

In October, she presented to the hospital with confusion, lethargy, dysarthria, worsening of movements, and decreased taste in her mouth and was found hypothermic a second time $\left(T: 33.5^{\circ} \mathrm{C}\right)$ (see Table 1). Her blood results showed hyponatraemia $(127 \mathrm{mmol} / \mathrm{l})$, normokalaemia $(4.4 \mathrm{mmol} / \mathrm{l})$, decreased serum osmolality $(269 \mathrm{mOsm} / \mathrm{kg})$ with a urine osmolality of $368 \mathrm{mOsm} / \mathrm{kg}$, and no evidence of extracellular space depletion. Her general status gradually improved while still hypothermic $\left(T: 34.3^{\circ} \mathrm{C}\right)$ and after five days she was discharged. Regular monitoring of her electrolyte levels was arranged.

After the third hospitalisation with unexplained hypothermia, our patient was readmitted a fourth time in December with lethargy, dysarthria, and limb weakness (see Table 1). Once again she was found hypothermic $\left(T: 33.0^{\circ} \mathrm{C}\right)$ and bradycardic. She was treated empirically for urosepsis with IV tazocin, which was then switched to nitrofurantoin as blood tests did not suggest an infectious cause. Thyroid function tests (TFTs), cortisol, Vitamin D, prolactin, parathyroid hormone $(\mathrm{PTH})$, and $\mathrm{Ca}^{2+}$ levels were within range and a liver autoimmune screen was negative. A second brain MRI (1.5 T) showed heavy demyelinating disease burden, but no hypothalamic involvement and a likely incidental small frontal meningioma. She was discharged after two weeks, asymptomatic while still hypothermic $\left(T: 34.0^{\circ} \mathrm{C}\right)$.
Between March 2014 and March 2015, our patient was hospitalised nine more times (see Table 1). Confusion, lethargy, fatigue, dysarthria, and motor weakness were the most common symptoms and associated hypothermia was registered on at least six admissions. Interestingly, on two occasions, she presented with relatively abnormal high temperatures $\left(T: 37.4^{\circ} \mathrm{C}\right.$ and $\left.T: 37.0^{\circ} \mathrm{C}\right)$.

UTI was considered the likely cause of her symptoms in six instances and antibiotics were prescribed. A threeday course of intravenous methylprednisolone was added once, with no apparent benefits and in most cases the patient recovered spontaneously. In the light of only two positive urinary samples, the absence of typical UTI symptoms, and a negative cystoscopy, urology recommended intermittent selfcatheterisation due to increased residual urine volume.

Following admission in October 2014, a repeat brain MRI with contrast was performed at $1.5 \mathrm{~T}$ that demonstrated recent callosal involvement (see Figure 1). A spinal MRI (1.5 T) was also arranged and revealed diffuse, patchy, T2 hyperintense lesions involving the majority of the cervical cord and T910 with associated atrophy (see Figure 1). These findings were discussed at the neuroradiology multidisciplinary team meeting and considered consistent with spinal MS rather than neuromyelitis optica spectrum disorder (NMOSD). This was confirmed by serology tests for anti-aquaporin 4 (AQP4) and anti-myelin oligodendrocyte glycoprotein (MOG) antibodies, which were both negative.

\section{Discussion}

Our patient developed clinical hypothermia $\left(T<35^{\circ} \mathrm{C}\right)$ associated with SP-MS. In the literature, this has been reported for 23 other MS cases (16 females) (see Table 2 ).

Most patients experienced deteriorations in cognition and consciousness (confusion, lethargy, or even stupor and coma) often accompanied by dysarthria (slurred speech) and worsening motor symptoms associated with hypothermia. On admission, their temperature ranged from $29.0^{\circ} \mathrm{C}$ to $35.0^{\circ} \mathrm{C}$ (see Table 2 ). In over half of these cases hypothermia had occurred after $>20$ years since diagnosis and was 


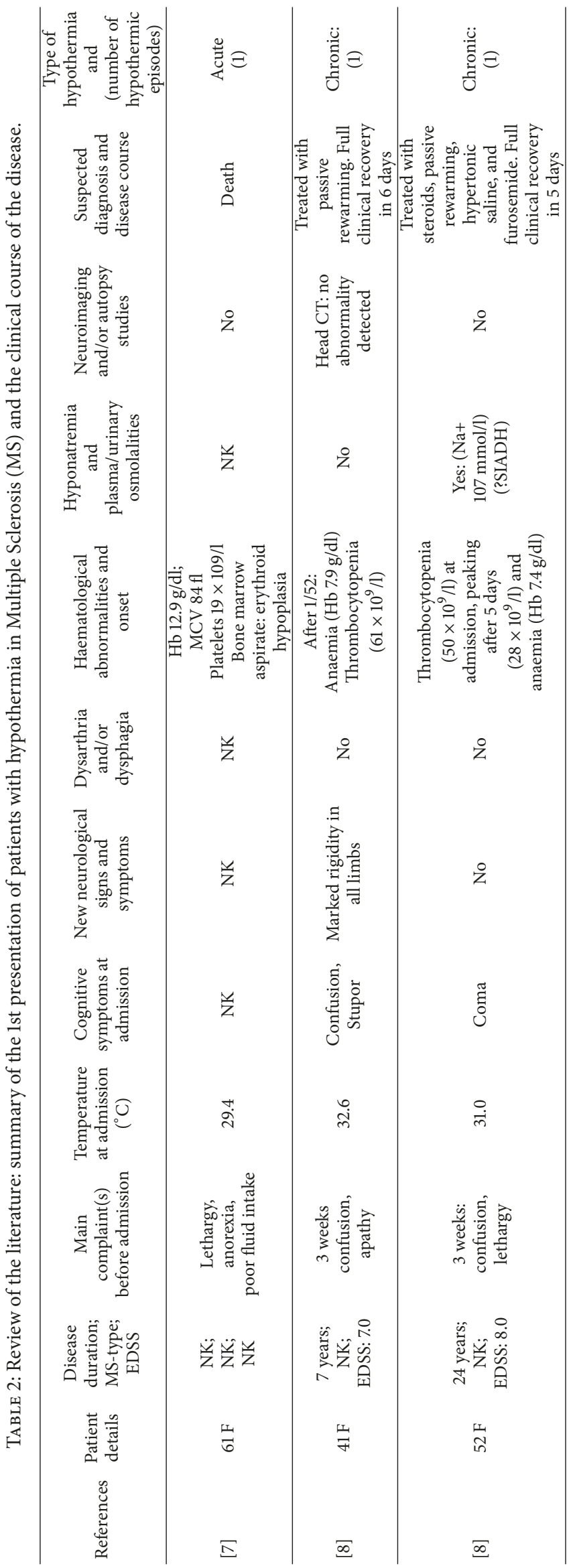




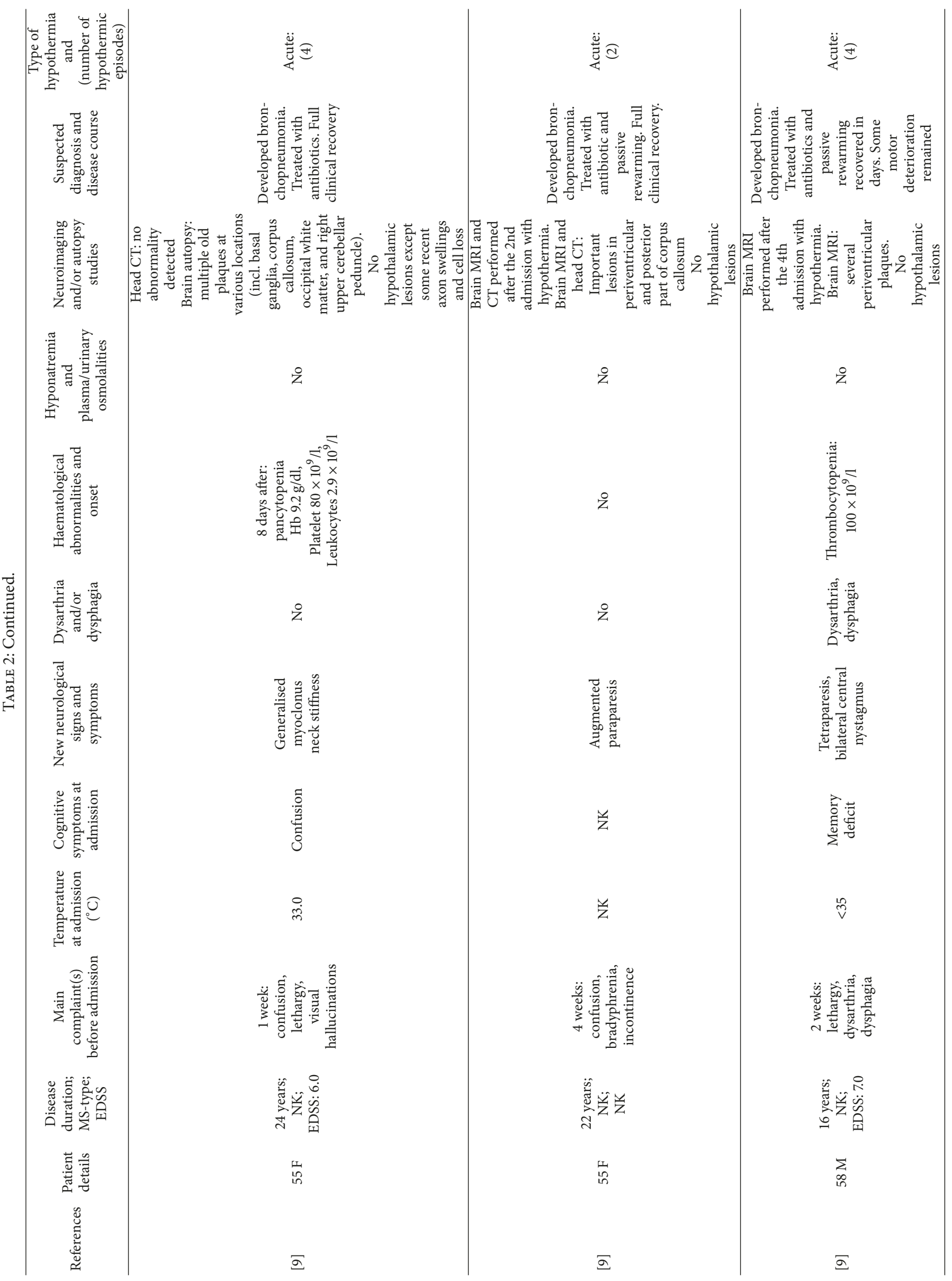




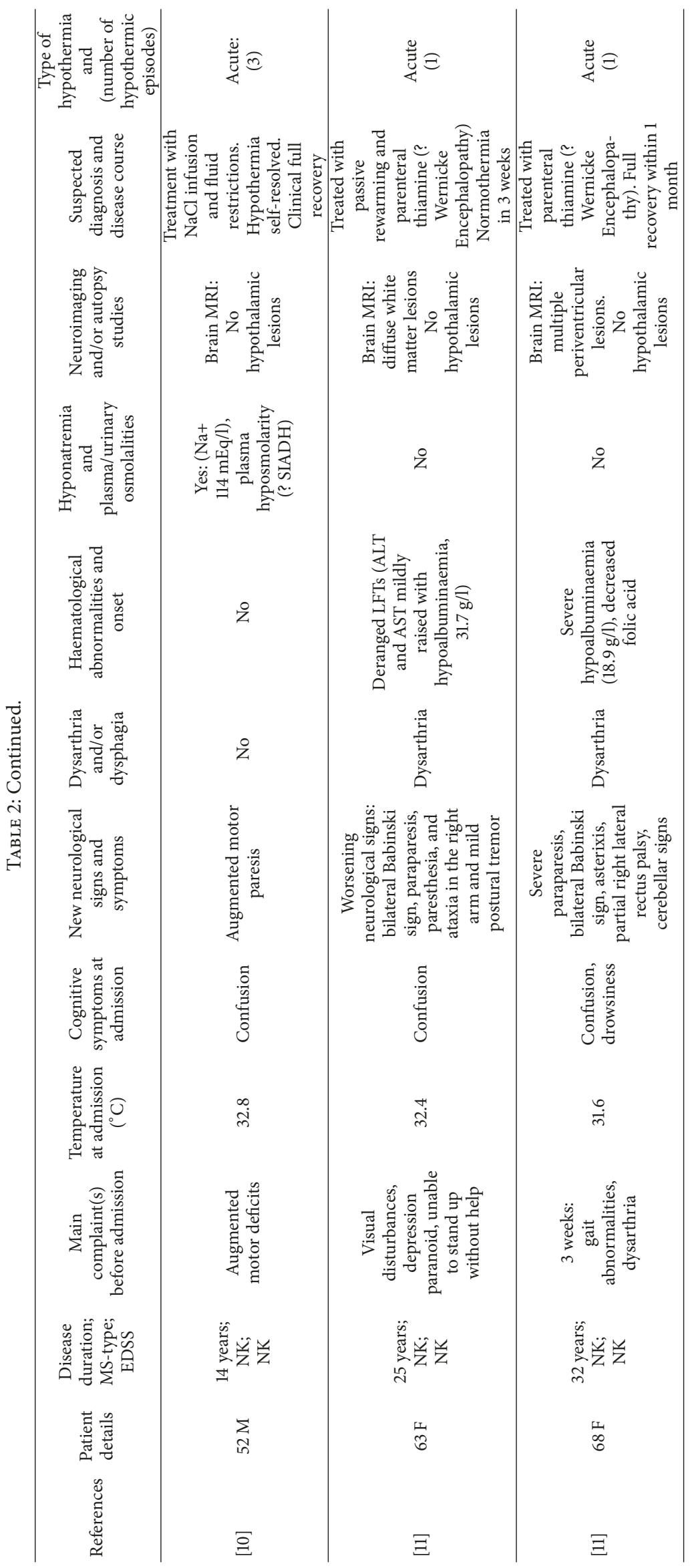




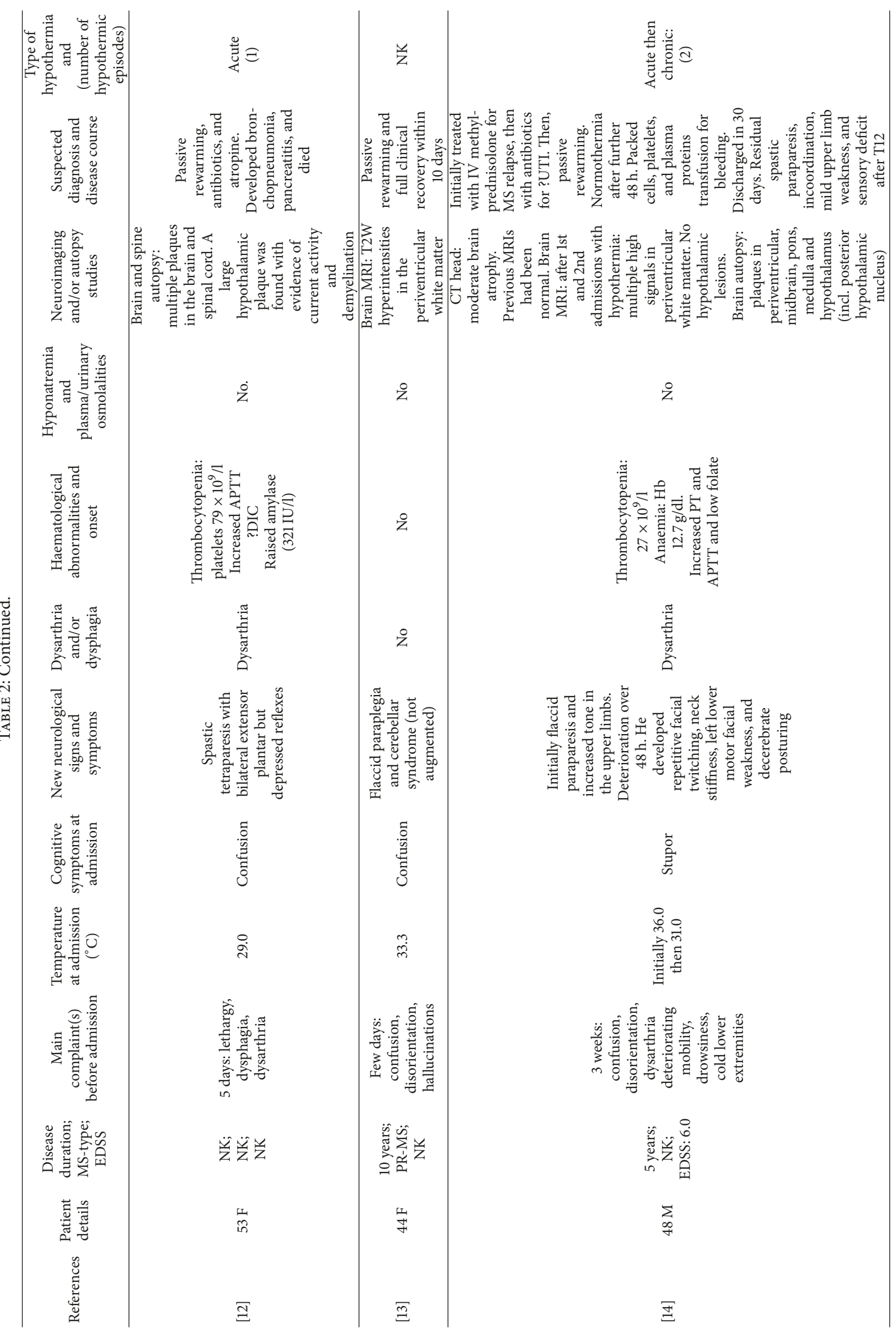




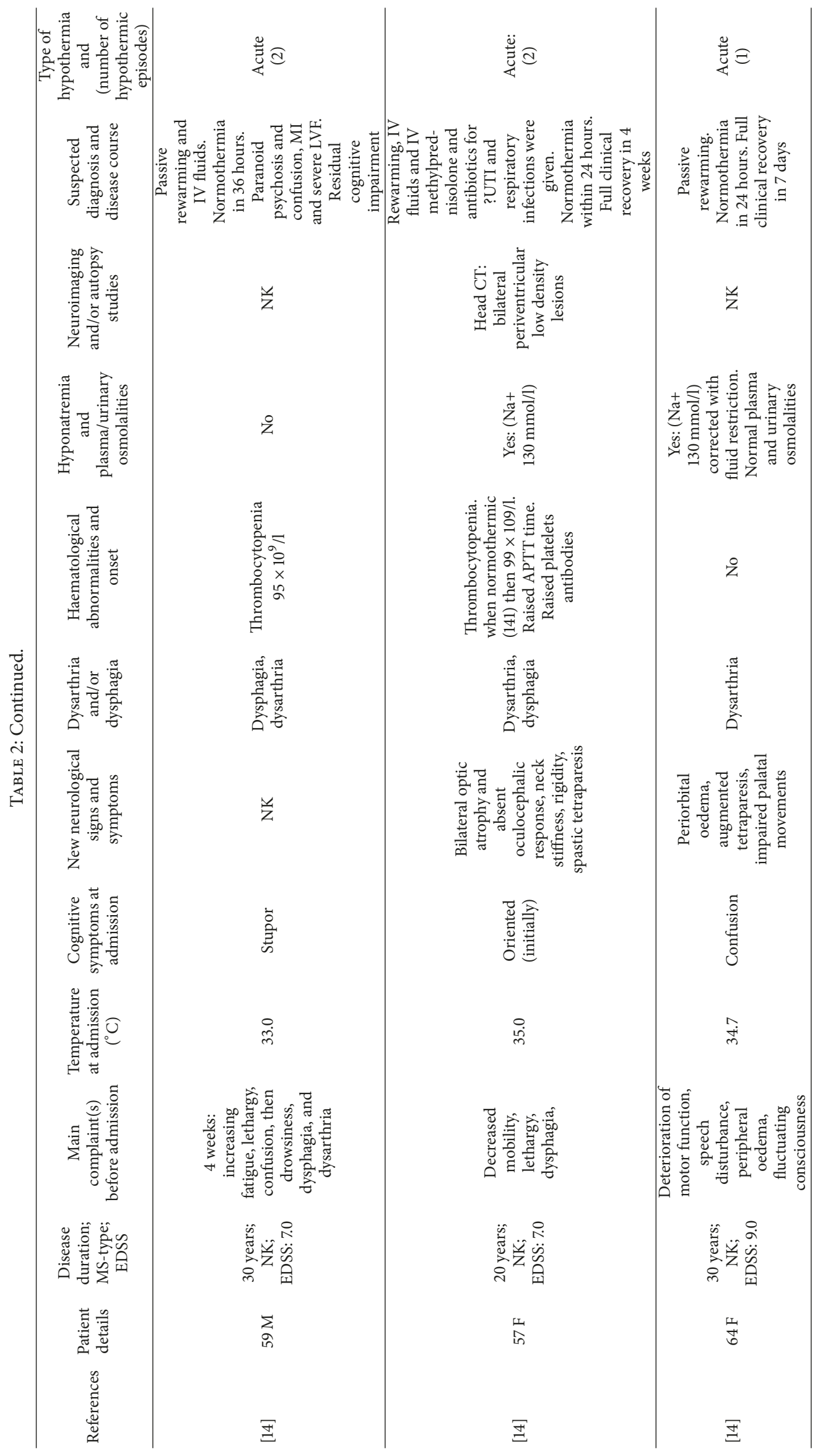




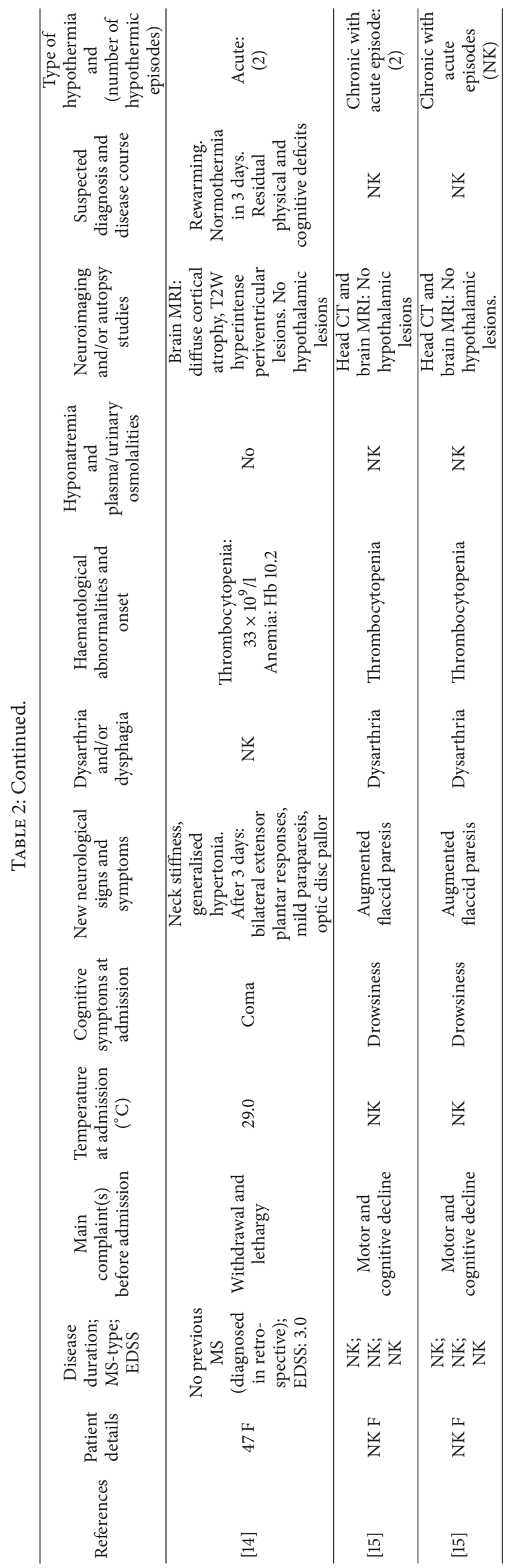




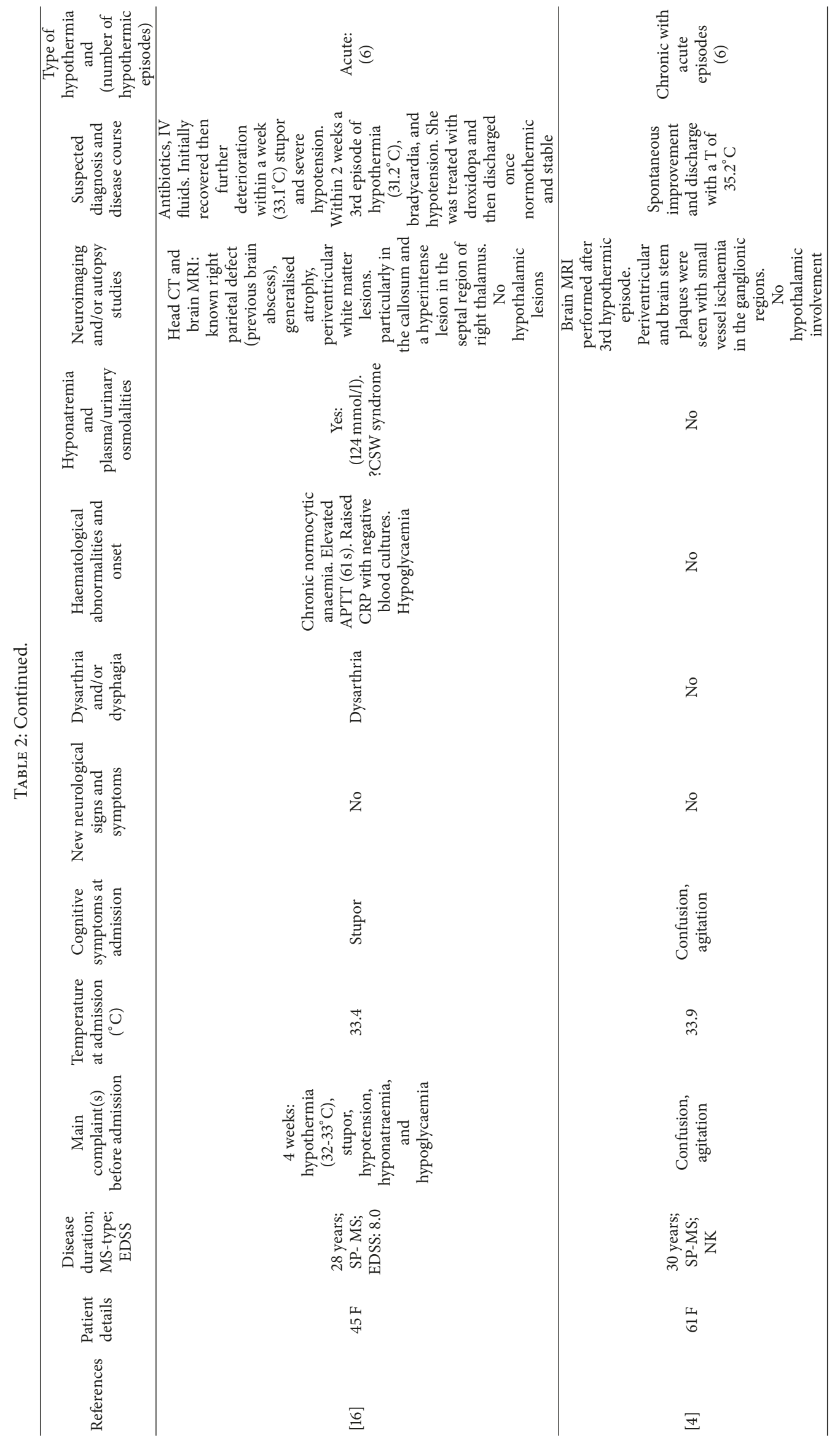




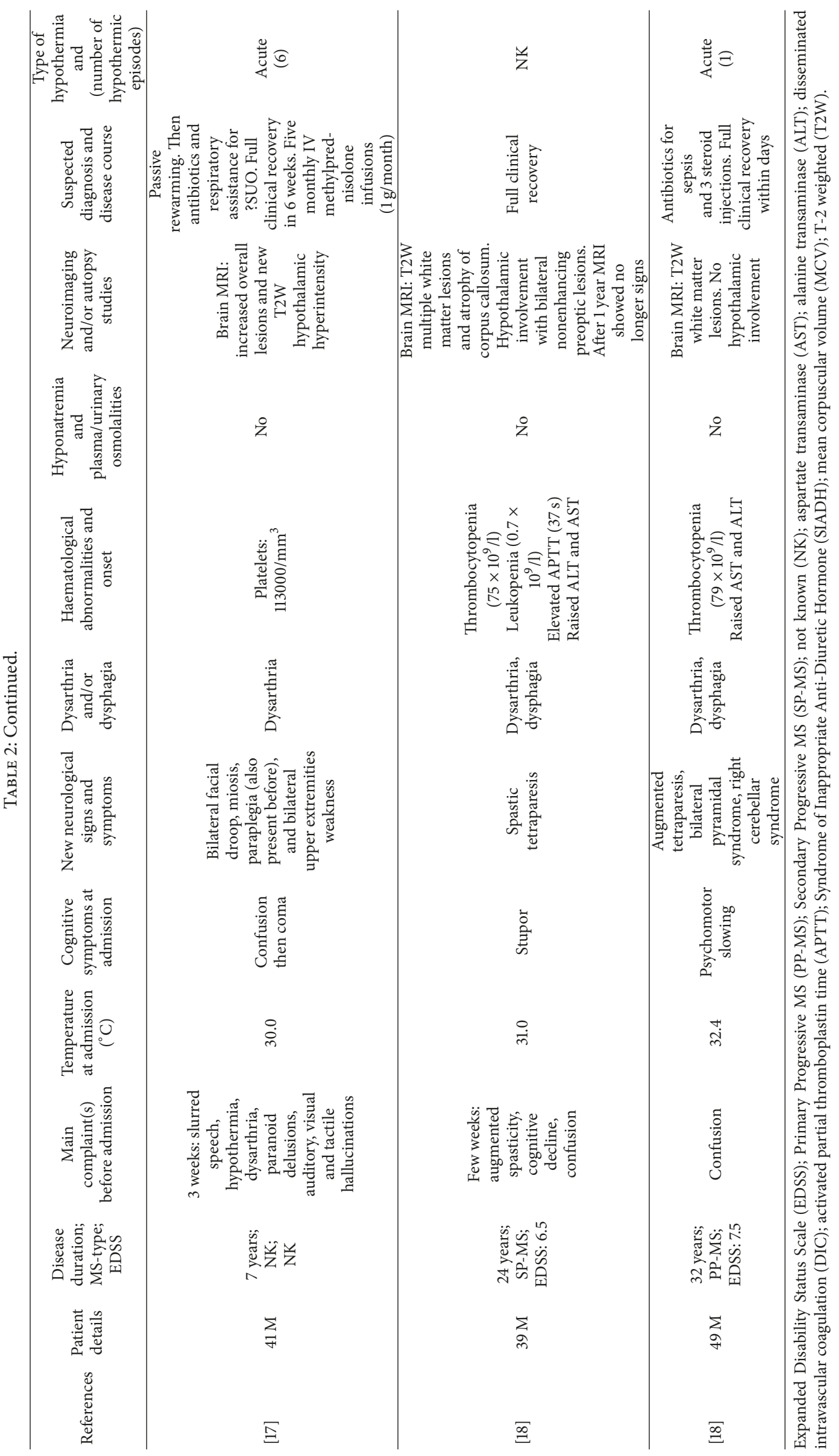


associated with severe disability (see Table 2). At least 12 of these patients suffered from more than one of such episodes (see Table 2).

Our patient developed more numerous episodes of hypothermia, superimposed on a chronic hypothermic state, than patients in previous reports. Chronic hypothermia was defined by the authors of this article as sustained hypothermia, typically lasting months. This had been previously reported in 5 other MS patients (see Table 2). In another case, chronic temperature changes were milder $\left(35.0-36.5^{\circ} \mathrm{C}\right)$; hence this did not match the clinical definition of hypothermia [14].

Most MS patients achieved full or partial recovery after the first admission with hypothermia (see Table 2). Two deaths were associated with the initial episode $[7,12]$ and other two with subsequent ones $[15,17]$. Transient haematological abnormalities were recorded in 16 patients during their first episode. Most commonly, these included thrombocytopenia and anaemia (see Table 2). Our anaemic patient, however, did not experience fluctuations of haematological parameters during admissions.

Previous cases of transiently deranged LFTs in hypothermic MS patients have been reported (see Table 2). In our case, mild, chronic LFT abnormalities could have been caused by Naltrexone-induced hepatic damage. Hyponatraemia was also reported in 5 of the previous cases (see Table 2). Cerebral salt wasting syndrome (CSW) and Syndrome of Inappropriate Anti-Diuretic Hormone (SIADH) both present with hyponatraemia and hyposmolality and while SIADH was suspected in this case, it was not formally confirmed. Irrespective of hypothermia, SIADH had been previously reported in MS and associated with the presence of periventricular and/or hypothalamic lesions $[19,20]$.

More controversial is the pathophysiology of hypothermia in MS, partly because of our limited understanding of thermoregulation. Recently, however, the anatomical basis of the thermoregulatory pathways has been further characterised, mostly in rodents, which share strong similarities on thermal reflexes with humans [5]. An understanding of the current model is helpful to elucidate the importance of different areas in thermoregulation (see Figure 2).

Most of the reports on hypothermic MS patients describe deficits along the thermoregulatory circuit described (see Figure 2). For instance, our patient mentioned to be "feeling cold" only twice and, in the other 23 cases, this symptom is rarely mentioned, suggesting an impairment of the afferent tracts. Similarly, shivering and sympathetic activation (leading to CVC, BAT, and an increase in RR, HR, and BP) are considered physiological responses to mild hypothermia $\left(32-35^{\circ} \mathrm{C}\right)[4]$ which were absent in our patient. In one of the early reports, two MS patients suffering from hypothermia were placed in a climatic chamber with a paraplegic pathological control subject [8]. They were exposed, in sequence, to environmental air temperatures of $27.0,15.0$, and $35.0^{\circ} \mathrm{C}$ for periods of 30-50 minutes [8]. Upon cold exposure, MS patients demonstrated cold awareness but impaired shivering and cutaneous vasoconstriction (CVC) and a small increase in the metabolic rate which resulted in a fall in core body temperature [8]. In the same conditions, the paraplegic control subject showed marked shivering and peripheral CVC, a more significant metabolic increase, and maintained core body temperature, as would be expected normally [8]. While no formal autonomic tests were arranged in our patient, no significant alterations of respiratory rate or heart rate were detected clinically or recorded in the observation charts.

Given that the hypothalamus is considered a key centre for thermoregulation, the focus of previous reports on hypothermia in MS was often on identifying hypothalamic lesions. In this case, a $3 \mathrm{~T} \mathrm{MRI}$ and, subsequently, two 1.5 T MRI scans with contrast failed to detect hypothalamic involvement. Brain MRI was recorded in 15 other hypothermic MS patients, but radiological evidence for hypothalamic involvement was poor $(n=2 ; 13 \%)$ and in both cases it involved the preoptic area (POA) $[17,18]$. Out of three brains which were examined postmortem, hypothalamic pathology was evident in two $[9,12,14]$ (see Table 2). Previous to autopsy, brain MRI had been performed in one of such cases but had failed to detect hypothalamic changes, despite identifying periventricular lesions [14]. Independently, an MRI study on 105 Caucasian patients, with clinically definite MS without hypothermia and typical lesions, revealed a similar (13\%) frequency of radiologically-detectable hypothalamic changes, using a 1.5 Tesla MRI scanner, with conventional protocols [21]. Instead, a postmortem study on 17 nonhypothermic MS patients found hypothalamic lesions in 16 brains (97\%), 60\% of which showed active inflammation [22]. Different factors may explain this disparity in results. Firstly, poor radiological sensitivity, particularly in the earlier reports on hypothermia in MS, may account for the low presence of hypothalamic lesions. Secondly, the patient cohorts of Qiu et al. [21] and Huitinga et al. [22] were different, with the latter having a greater mean age of disease duration which was statistically associated with a greater number of active hypothalamic lesions [22]. Although, using the current MR technology, we are unable to exclude very small hypothalamic lesions, we are mindful that the latter have not been found in other reported cases [14] and by contrast, they can be present in MS patients not affected by hypothermia.

Together with hypothalamic changes, callosal, brainstem, and spinal cord lesions were also detected at autopsy in hypothermic MS patients (see Table 2). All these areas have been previously associated with the development of hypothermic episodes and both the brainstem and the upper spinal cord are known as important thermoregulatory centres $[4,5,14]$ (see Figure 2).

Brain callosal involvement, for instance, was detected in our case (see Figure 1) and in other four hypothermic MS patients via MRI or autopsy (see Table 2). In one instance, this was associated with hypothalamic disease [18]. In another report, MRI hyperintensities in the right posterior thalamus were associated with generalised atrophy, displaying clinical similarities to Shapiro's syndrome [16]. This is characterised by the congenital agenesis of the corpus callosum, hyperhidrosis, and recurrent hypothermia [23].

Brainstem lesions were associated with hypothermia in two other MS cases [4, 14]. In addition, a mesodiencephalic haematoma has been reported to be associated with hypothermia in a non-MS patient [24]. 


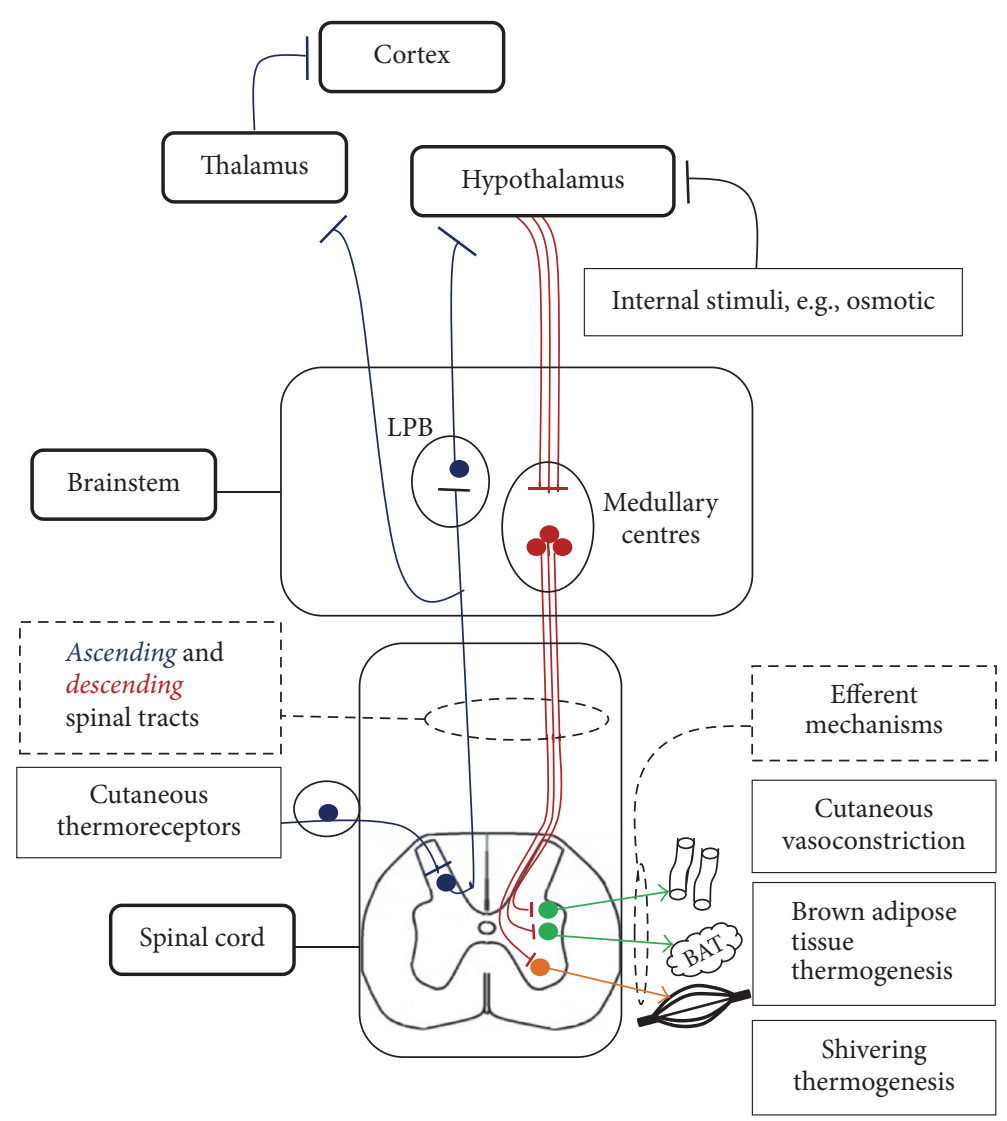

Figure 2: A schematic view of the main components of the thermoregulatory pathway according to the current main model $[5,6]$. It is thought that cool and warm-sensitive cutaneous thermoreceptors detect changes in skin temperature. These are relayed via parallel ascending spinal cords tracts, to the pontine lateral parabrachial nucleus (LPB) [5]. In turn, the LPB transmits these to the anterior hypothalamus [5]. Afferent information is also separately sent to the cortex (thalamocortical tract) [5]. The hypothalamus integrates these signals with sensory information from other areas like visceral thermoreceptors and osmoreceptors to generate an effector response. In physiological conditions, after an increase in cutaneous cool signals is detected by the hypothalamic median preoptic subnucleus (MnPO) of the Preoptic Area (POA), disinhibition of the efferent pathways (in red color) leads to the activation of the three main heat-maintenance/producing mechanisms [5]. The rostral ventromedial medulla, including the rostral raphe pallidus nucleus ( $\mathrm{rRPa}$ ), is considered a key supraspinal area which regulates cutaneous vasoconstriction (CVC) and brown adipose tissue (BAT) thermogenesis (sympathetic (in green color)) and shivering thermogenesis (somatic (in orange color)) $[5,6]$.

Upper spinal cord pathology in MS could also be associated with hypothermia. Spinal involvement of the cervical region is particularly common in MS and involves both white and grey matter, interneurons and motoneurons $[25,26]$. Similarly to brainstem lesions, upper spinal cord changes could impair both ascending and descending tracts of the thermoregulatory circuit (see Figure 2). Extensive spinal cord lesions associated with brain and hypothalamic involvement were found at autopsy in one MS patient [12] and were radiologically detected in ours (see Figure 1). In the previously reported cases, however, spinal MRI was never reported and in ours it was only performed once, after repeated episodes of hypothermia. Hence, our ability to directly estimate the impact of spinal lesions on the development of hypothermia in MS is limited.

Given the prominent spinal involvement, the differential diagnosis of neuromyelitis optica spectrum disorder (NMOSD) was discussed at a neuroradiology meeting but was ruled out on the basis of clinical presentation, radiological features (multiple, confluent patchy lesions rather than longitudinally extensive lesions), and serology results (anti-AQP4 and anti-MOG antibody negative) [27].

Of note, hypothermia with autonomic impairment is commonly observed after upper Spinal Cord Injury (SCI) $[28,29]$. A retrospective study of 50 tetraplegic patients found that subnormal core body temperatures $\left(35.0-36.4^{\circ} \mathrm{C}\right)$ were present in all patients and clinical hypothermia was recorded in 15 [30]. Similarities between dysfunctional sympathetic sudomotor skin responses were also identified among patients with transection of the SC at different levels and MS patients [31]. In spite of these resemblances and the frequent involvement of the spinal cord in MS, spinal lesions have not been reported to cause hypothermia in MS. This may be because, similarly to other lesions, a critical impairment of conduction is required before symptoms become manifest and in MS, unlike after SCI, this process is progressive and difficult to monitor. 
Interestingly, our patient developed two episodes of abnormally high temperatures (above $36.5^{\circ} \mathrm{C}$ ), associated with admissions (see Table 1). A clinical decay at high temperatures has been previously documented in MS patients ("Uhthoff's phenomenon") but, to our knowledge, was never reported to cause admissions in hypothermic individuals. This effect likely stems from decreased axonal conduction in damaged nerves at higher temperatures $[32,33]$. Why this phenomenon occurs at lower temperatures in chronically hypothermic MS patients is controversial. This may indicate a more severe axonal damage or simply the resetting of the body thermostat at a new lower point where these higher temperatures are considered extreme $[4,17]$.

Regardless of the causative mechanisms, no effective strategies have been devised to treat and prevent the development of hypothermic episodes in MS patients. Antibiotic treatment, in the absence of signs of infection, did not show any objective benefit for our patient and is known to promote antimicrobial resistance. Spontaneous recovery was commonly reported [18]. Treatment with steroids was shown to be potentially beneficial [17] but in our experience did not lead to substantial improvements. Our patient used an electrical blanket to control her body temperature at home, but the usefulness of this measure has not been systematically assessed. However, its use seems logical to prevent hypothermia since the neurological impairments along the thermoregulatory circuit.

\section{Conclusion}

In summary, hypothermia in MS patients remains a poorly understood phenomenon. The anatomical location of the causative lesions remains controversial and, based on the available evidence [4-6], we hypothesise that upper spinal cord, as well as brain stem lesions, may be involved in its pathogenesis in MS, independently of hypothalamic pathology. Given the disseminated nature of the disease, multiple, anatomically distinguished lesions, as opposed to a large single lesion, may also contribute to the development of this advanced complication by disrupting the thermoregulatory network at different levels [18]. In our opinion, in hypothermic MS patients, spinal MRI should be added to brain MRI to verify the presence of spinal involvement, due to its clinical importance. With the development of more sensitive neuroimaging and follow-up scans, anticipating the clinical course of hypothermia in these patients may be possible. Currently, in fact, the development of chronic hypothermia remains unpredictable.

\section{Consent}

Written informed consent was obtained from this patient for publication of this case report and all relevant material.

\section{Conflicts of Interest}

The authors declare that there are no conflicts of interest regarding the publication of this article.

\section{Acknowledgments}

In loving memory of our patient, who passed away at Nottingham University Hospitals on 15 December 2017, the authors wish to thank her and her family for their support and encouragement.

\section{References}

[1] C. A. Dendrou, L. Fugger, and M. A. Friese, "Immunopathology of multiple sclerosis," Nature Reviews Immunology, vol. 15, no. 9, pp. 545-558, 2015.

[2] M. M. Goldenberg, "Multiple Sclerosis Review" http://www .pubmedcentral.nih.gov/articlerender.fcgi?artid=3351877\&tool= pmcentrez\&rendertype $=$ abstract.

[3] M. M. Vellinga, J. J. G. Geurts, E. Rostrup et al., "Clinical correlations of brain lesion distribution in multiple sclerosis," Journal of Magnetic Resonance Imaging, vol. 29, no. 4, pp. 768-773, 2009.

[4] J. E. Alty and H. L. Ford, "Multi-system complications of hypothermia: A case of recurrent episodic hypothermia with a review of the pathophysiology of hypothermia," Postgraduate Medical Journal, vol. 84, no. 992, pp. 282-286, 2008.

[5] S. F. Morrison, "Central neural control of thermoregulation and brown adipose tissue," Autonomic Neuroscience: Basic \& Clinical, vol. 196, pp. 14-24, 2016.

[6] K. Nakamura, "Central circuitries for body temperature regulation and fever," American Journal of Physiology-Regulatory, Integrative and Comparative Physiology, vol. 301, no. 5, pp. R1207-R1228, 2011.

[7] H. O'Brien, J. A. Amess, and D. L. Mollin, "Recurrent thrombocytopenia, erythroid hypoplasia and sideroblastic anaemia associated with hypothermia," British Journal of Haematology, vol. 51, Article ID 7104229, pp. 451-456, 1982, http://www.ncbi .nlm.nih.gov/entrez/query.fcgi? $\mathrm{cmd}=$ Retrieve $\& \mathrm{db}=\mathrm{PubMed} \&$ $\mathrm{dopt}=$ Citation\&list_uids $=7104229$.

[8] F. Sullivan, M. Hutchinson, S. Bahandeka, and R. E. Moore, "Chronic hypothermia in multiple sclerosis," Journal of Neurology, Neurosurgery \& Psychiatry, vol. 50, no. 6, pp. 813-815, 1987.

[9] M. Lammens, F. Lissoir, and H. Carton, "Hypothermia in three patients with multiple sclerosis," Clinical Neurology and Neurosurgery, vol. 91, no. 2, pp. 117-121, 1989.

[10] F. Ghawche and A. Destée, "Hypothermia and multiple sclerosis. A case with 3 episodes of transient hypothermia," in Nature Reviews Neurology, vol. 146, pp. 767-769, 1990.

[11] C. Geny, P. F. Pradat, J. Yulis, S. Walter, D. Cesaro, and J. D. Degos, "Hypothermia, Wernicke encephalopathy and multiple sclerosis," Acta Neurologica Scandinavica, vol. 86, no. 6, pp. 632634, 1992.

[12] S. Edwards, G. Lennox, K. Robson, and A. Whiteley, "Hypothermia due to hypothalamic involvement in multiple sclerosis," Journal of Neurology, Neurosurgery \& Psychiatry, vol. 61, no. 4, pp. 419-420, 1996.

[13] P. Mouton, F. Woimant, and O. Ille, "Hypothermia and the nervous system. Review of the literature apropos of 4 cases," Annales De Medecine Interne, vol. 147, pp. 107-114, 1996.

[14] K. D. White, D. J. Scoones, and P. K. Newman, "Hypothermia in multiple sclerosis," Journal of Neurology, Neurosurgery \& Psychiatry, vol. 61, no. 4, pp. 369-375, 1996.

[15] W. Feneberg and N. H. König, "Two cases of hypothermia in multiple sclerosis," Journal of Neurology, vol. 253, no. S1, pp. i37i37, 2006. 
[16] R. A. Linker, A. Mohr, L. Cepek, R. Gold, and H. Prange, "Core hypothermia in multiple sclerosis: Case report with magnetic resonance imaging localization of a thalamic lesion," Multiple Sclerosis Journal, vol. 12, no. 1, pp. 112-115, 2006.

[17] N. Weiss, D. Hasboun, S. Demeret et al., "Paroxysmal hypothermia as a clinical feature of multiple sclerosis," Neurology, vol. 72, no. 2, pp. 193-195, 2009.

[18] A. Darlix, G. Mathey, and M-L. Monin, "Hypothalamic involvement in multiple sclerosis," Nature Reviews Neurology, vol. 168, pp. 434-443, 2012.

[19] E. Ishikawa, S. Ohgo, K. Nakatsuru et al., "Syndrome of Inappropriate Secretion of Antidiuretic Hormone (SIADH) in a Patient with Multiple Sclerosis," Japanese Journal of Medicine , vol. 28, no. 1, pp. 75-79, 1989.

[20] G. Liamis and M. Elisaf, "Syndrome of inappropriate antidiuresis associated with multiple sclerosis," Journal of the Neurological Sciences, vol. 172, Article ID 0033989706, pp. 38-40, 2000, http://www.scopus.com/inward/record.url?eid=2-s2.0-0033989706\&partnerID $=40 \& \mathrm{md} 5=5 \mathrm{aa} 44931 \mathrm{a} 75 \mathrm{f} 7 \mathrm{f} 11 \mathrm{bbc08886a00d}$ $943 \mathrm{c} \% 255 \mathrm{Cn}$.

[21] W. Qiu, S. Raven, J. Wu et al., "Hypothalamic lesions in multiple sclerosis," Journal of Neurology, Neurosurgery \& Psychiatry, vol. 82, no. 7, pp. 819-822, 2011.

[22] I. Huitinga, C. J. De Groot, P. Van der Valk, W. Kamphorst, F. J. Tilders, and D. F. Swaab, "Hypothalamic lesions in multiple sclerosis," Journal of Neuropathology \& Experimental Neurology, vol. 60, no. 12, pp. 1208-1218, 2001.

[23] W. R. Shapiro, G. H. Williams, and F. Plum, "Spontaneous recurrent hypothermia accompanying agenesis of the corpus callosum," Brain, vol. 92, no. 2, pp. 423-436, 1969.

[24] G. Gaymard, H. Cambon, D. Dormont, A. Richard, and C. Derouesne, "Hypothermia in a mesodiencephalic haematoma," Journal of Neurology, Neurosurgery \& Psychiatry, vol. 53, no. 11, pp. 1014-1015, 1990.

[25] C. P. Gilmore, J. J. G. Geurts, N. Evangelou et al., "Spinal cord grey matter lesions in multiple sclerosis detected by postmortem high field MR imaging," Multiple Sclerosis Journal, vol. 15, no. 2, pp. 180-188, 2009.

[26] C. Lukas, M. H. Sombekke, B. Bellenberg et al., "Relevance of spinal cord abnormalities to clinical disability in multiple sclerosis: MR imaging findings in a large cohort of patients," Radiology, vol. 269, no. 2, pp. 542-552, 2013.

[27] D. M. Wingerchuk, B. Banwell, J. L. Bennett et al., "International consensus diagnostic criteria for neuromyelitis optica spectrum disorders," Neurology, vol. 85, no. 2, pp. 177-189, 2015.

[28] M. Menard and G. Hahn, "Acute and chronic hypothermia in a man with spinal cord injury: environmental and pharmacologic causes," Archives of Physical Medicine and Rehabilitation, vol. 72, pp. 421-424, 1991.

[29] S. C. Colachis III, "Hypothermia associated with autonomic dysreflexia after traumatic spinal cord injury," American Journal of Physical Medicine \& Rehabilitation, vol. 81, no. 3, pp. 232-235, 2002.

[30] S. Khan, M. Plummer, A. Martinez-Arizala, and K. Banovac, "Hypothermia in patients with chronic spinal cord injury," The Journal of Spinal Cord Medicine, vol. 30, no. 1, pp. 27-30, 2007.

[31] T. Yokota, T. Matsunaga, R. Okiyama et al., "Sympathetic skin response in patients with multiple sclerosis compared with patients with spinal cord transection and normal controls," Brain, vol. 114, no. 3, pp. 1381-1394, 1991.
[32] W. Uhthoff, "Untersuchungen über die bei der multiplen Herdsklerose vorkonimenden Augenstörungen," Archiv für Psychiatrie und Nervenkrankheiten, vol. 21, no. 2, pp. 305-410, 1890.

[33] S. L. Davis, T. C. Frohman, C. G. Crandall et al., "Modeling Uhthoff's phenomenon in MS patients with internuclear ophthalmoparesis," Neurology, vol. 70, no. 13, pp. 1098-1106, 2008. 


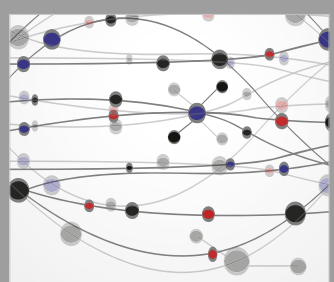

The Scientific World Journal
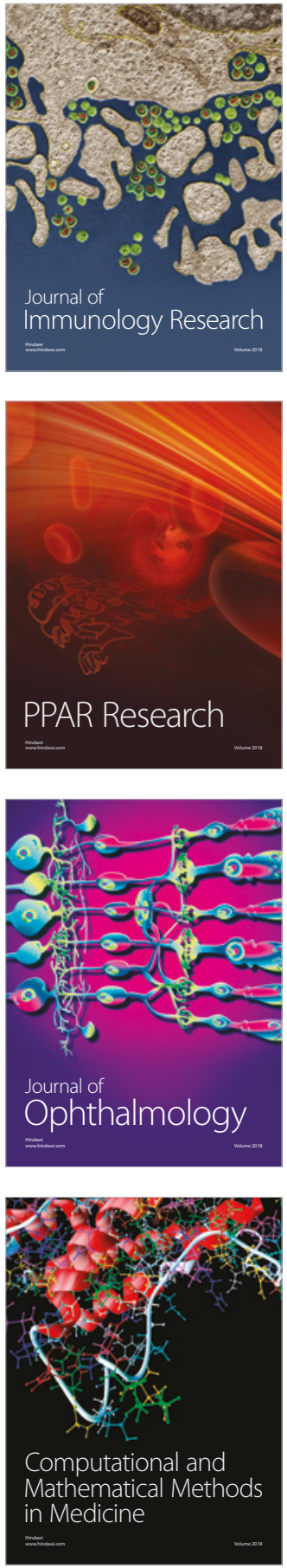

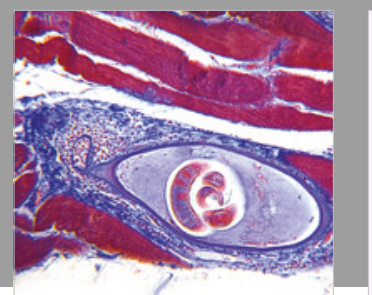

Gastroenterology Research and Practice

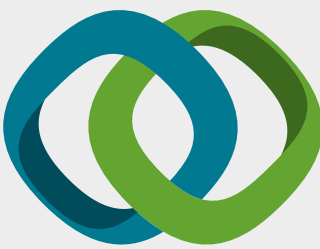

\section{Hindawi}

Submit your manuscripts at

www.hindawi.com
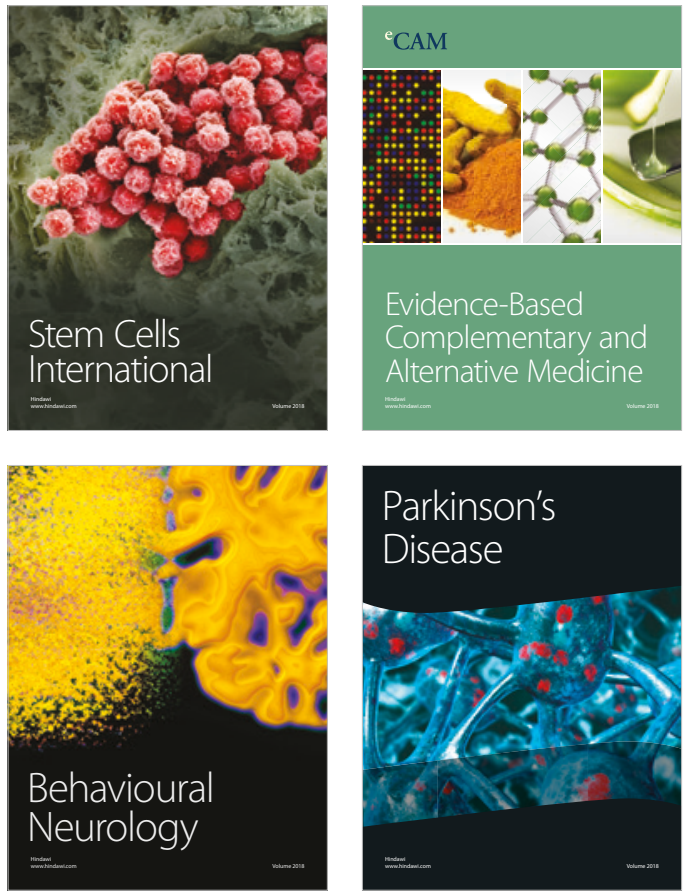

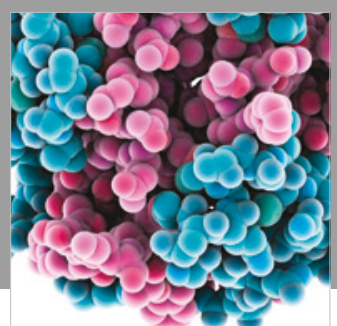

ournal of

Diabetes Research

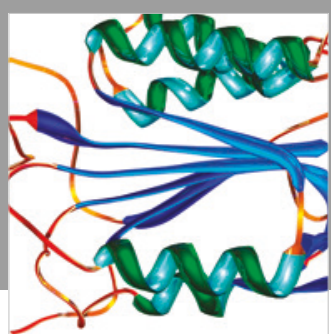

Disease Markers
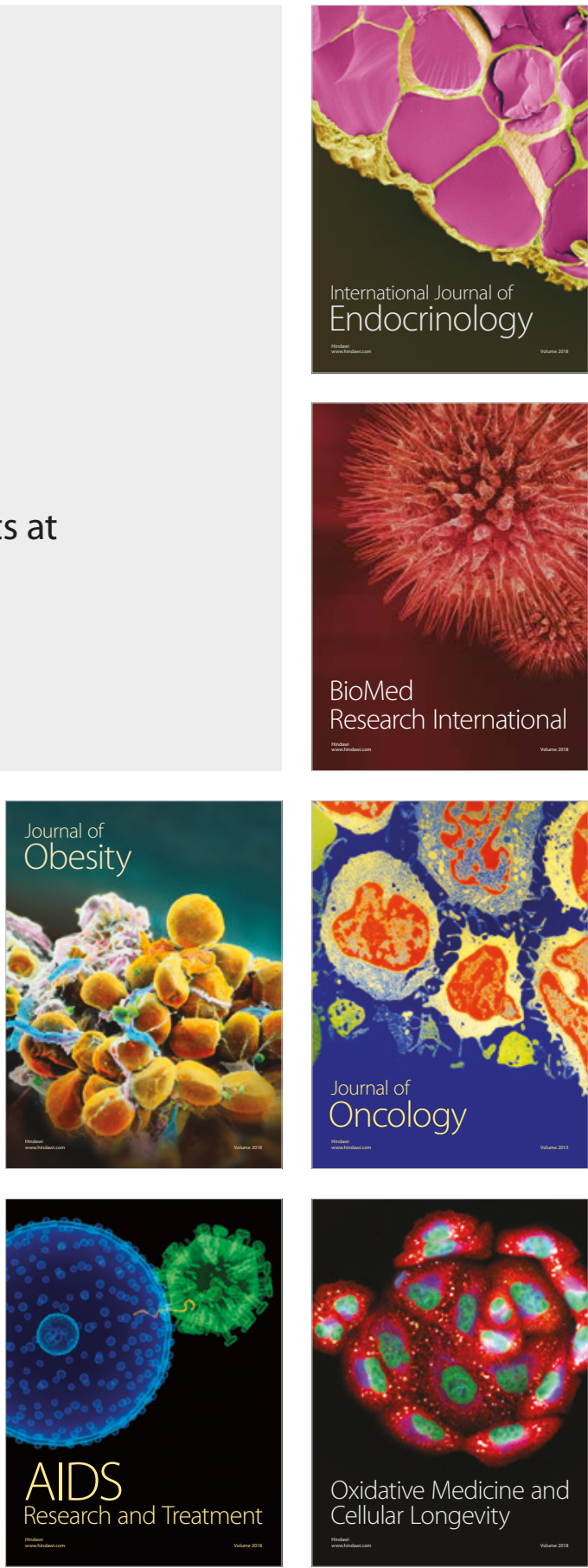